\title{
Multifunctional agriculture: A framework and policy design ${ }^{1}$
}

\author{
Jussi Lankoski ${ }^{1)}$, Markku Ollikainen ${ }^{2)}$ \\ ${ }^{1)}$ MTT Taloustutkimus, PL 3,00411 Helsinki, jussi.lankoski@mtt.fi \\ ${ }^{2)}$ Taloustieteen laitos, PL 27, 00014 Helsingin yliopisto,markku.ollikainen@helsinki.fi
}

\section{Introduction}

Multifunctional agriculture refers to the fact that agriculture produces jointly a number of food and nonfood outputs, some of which exhibit the characteristics of externalities and public goods (OECD 2001). The primary source of this joint production is technical interdependence in the use of inputs and it is reinforced also by allocable fixed (or quasi-fixed) inputs, such as land (Shumway et al. 1984).

In this paper we suggest an analytical framework for designing socially optimal multifunctional agriculture. We use Lichtenberg's model of agricultural production (1989), where the quality of lands varies and the land use patterns among crops are determined on the basis of relative rents. We augment this model by a description of landscape diversity, diversity of agroecosystems and nutrient runoff, which are linked to input and land allocation choices.

The farmer's privately optimal use of inputs, and land allocation create a market solution for nutrient runoffs and, through the landscape mosaic, for ecosystem diversity as well. We compare the private solution to the socially optimal way of producing both food and non-food products. Then we investigate the optimal use of two instruments, namely, a fertilizer tax and a buffer strip subsidy, to guide the private solution towards social optimum. Finally, we illustrate in a numerical application how to determine the use of inputs and land allocation, which maximizes social welfare from multifunctional agriculture, and how to design policy instruments so as to achieve this optimum with decentralized decisions by farmers.

\section{Analytical Model}

In our analytical model we show that the private use of fertilizer input is higher and the size of buffer strips lower than the socially optimal solution requires. Also the socially optimal land allocation differs from the private solution due to the valuation of landscape diversity and runoff damages. The optimal policy is to use a differentiated fertilizer tax and a differentiated buffer strip subsidy and to determine their levels by the equality between the net value of their marginal product in food production and their effects on the marginal valuation of diversity and runoff damage in each parcel.

\section{Parametric Model}

By using Finnish data we determine the basic features of socially optimal multifunctional agriculture and design optimal fertilizer tax (nitrogen tax) and buffer strip subsidy rates that can sustain this optimality. We first solve numerically both the private optimum in the absence of instruments as well as the command optimum. The latter allows us to define the rates of differentiated fertilizer tax and buffer strip subsidy so as to maximize the social welfare function. We then solve for a uniform fertilizer tax and buffer strip subsidy for each crop as a second-best solution. Finally, we compare the privately optimal solution in the absence of taxes and subsidies and under the second-best instruments with the command optimum. Comparisons are made in terms of land allocation, short-run profits, runoffs and diversity, for which we offer two measures, floral species richness (species diversity of agroecosystem) and Shannon's diversity index (landscape diversity), and finally in terms of social welfare under alternative solutions.

\footnotetext{
${ }^{1}$ We are grateful for Juha Helenius, Maohua Ma and Sanna Tarmi for useful discussions, professional expertise and for providing empirical data concerning the relationship between species richness and buffer strip areas. Antti Miettinen and Bjorn Sandvik gave us helpful comments on an earlier version of this paper. Chiara Lombardini-Riipinen provided us competent assistance in making empirical calculation in Mathematica.
} 
The arable land area is assumed to be 60 hectares. The calculation of the Shannon's diversity index requires assumptions concerning the specific shape of the field. We assume that the height of the field is $500 \mathrm{~m}$ and the length is $1200 \mathrm{~m}$. The base case of our parametric model represents the private market solution (without taxes and subsidies) for cereals in Finland in 1999.

In the parametric model we apply a quadratic nitrogen response function (with parameters estimated for barley (crop 1) and wheat (crop 2) in clay soils by Bäckman et al. 1997) $y_{i}=a_{i}+\alpha_{i} l_{i}+\beta_{i} l_{i}^{2}$. Land quality $q$ is continuous and incorporated through the intercept parameter $a_{\mathrm{i}}$, which is assumed to increase linearly. The representative farmer's short-run profit per parcel for crop $i$ in the presence of a fertilizer tax and buffer strip subsidy is given by

$\pi^{i}=p_{i}\left(1-m_{i}\right)\left[a_{i}+\alpha_{i} l_{i}+\beta_{i} l_{i}^{2}\right]-c^{*} l_{i}+\left(\lambda-\frac{1}{2} \lambda m_{i}\right) m_{i}$ for $i=1,2, \quad$ where $m_{\mathrm{i}}$ is buffer strip area, $p_{i}$ is crop price and $c$ is fertilizer price, a fertilizer tax, $t$, is levied on the use of fertilizers, so that the after-tax price of fertilizer is $c^{*}=c(1+t), \lambda$ is the maximum level of buffer strip subsidy.

Nitrogen runoffs $Z_{\mathrm{i}}$ are given by $Z_{i}=(1-j r) y\left(N_{i}\right)$ for $i=1,2$, where $Z_{i}=$ nitrogen runoff, $y\left(N_{i}\right)=$ nitrogen runoff at fertilizer intensity level $N_{i}, \mathrm{~kg} / \mathrm{ha}, j=$ share of the surface runoff of combined surface and drainage runoff, and $r=$ nitrogen removal effectiveness of the buffer strip.

For the social value of runoff damages we use an estimate provided by Vehkasalo (1999). He approximated the social benefits of reducing nitrogen runoffs from Finnish agriculture by applying the averting expenditure valuation method, and estimated the costs of a corresponding nitrogen reduction at municipal wastewater treatment facilities. The cost estimate is FIM 9.5 per reduced $\mathrm{kg}$ of nitrogen (when 10 to 20 per cent of the total nitrogen load is reduced). We assume a convex damage function from runoffs, i.e. $d(z)=(9,5+0,024 z) z$.

Our estimate for agroecosystem diversity valuation function is given in buffer strip hectares. By using the contingent valuation method, Aakkula (1999) provides an estimate for the economic value of pro-environmental farming in Finland (pro-environmental farming was defined as an economic activity that enhances environmental and ecological quality of the rural environment). He found that the average WTP/ha for pro-environmental farming was FIM 466. However, besides landscape diversity and the diversity of agroecosystems, this estimate also includes the value of nutrient runoff reduction. Therefore, we use the estimate of FIM 326 per hectare, which is 30\% lower than Aakkula's average WTP. This $30 \%$ reduction closely corresponds to Vehkasalo's runoff damage estimate FIM 147,9 at the average runoff level of $15 \mathrm{~kg} \mathrm{~N} / \mathrm{ha}$. Therefore, we will use the following concave valuation function for agroecosystem diversity, i.e. $\mu=\left(340-70 m_{i}\right) m_{i}$.

We link agroecosystem diversity valuation function to species diversity with the help of a study by Ma et al. (2001), which focuses on the relationship between floral species richness and buffer strip area using Finnish data. Ma et al. take as their starting point the conventional species-area relationship, $S=\psi A^{\varphi}$, where $S$ is species richness, $A$ is area, $\psi$ is the number of species in the initial area, and $\varphi$ describes the rate of species increase along with the increase of area. Then Ma et al. modify this relationship to include the length $(L)$ and the width $(W)$ of the buffer strip area as follows $S=\psi L^{\varphi_{\alpha}} W^{\varphi_{\beta}}$, where $\varphi_{\alpha}\left(\varphi_{B}\right)$ is an estimate for the average change in species richness due to an increase in the length (width) of the area while keeping the width (length) of the area constant. Hence, after having solved for $m$, we can assess the floral species richness by using the following coefficients estimated by Ma et al. (2001): $\psi=1.6331, \varphi_{\alpha}=0.0009, \varphi_{\beta}=0.0977$.

Finally, we apply ex post the Shannon Diversity Index (SHDI) as a measure of landscape diversity (see Eiden et al. 2000). The Shannon Diversity Index (SHDI) is calculated by adding for each patch type in a reference area the proportion of area covered by that patch type multiplied by the natural logarithm of that proportion $S H D I=-\sum_{i=1}^{n}\left(P_{i} * \ln P_{i}\right)$, where $n=$ number of patch types and $P_{\mathrm{i}}=$ the proportion of the area covered by patch type $i$. 


\section{Results}

The first two rows in Table 1 condense the economic and environmental features of the private market solution and command optimum. We report land allocation, short-run profits, nitrogen runoffs, floral species richness, Shannon Diversity Index $(S H D I)$, and the social welfare $(S W)$, which is calculated as a sum of profits, runoff damage and diversity benefits.

Table 1. Results

\begin{tabular}{|c|c|c|c|c|c|c|}
\hline Policy & $\begin{array}{l}\text { Land allocation, ha } \\
\text { crop } 1 \text { and crop } 2\end{array}$ & $\begin{array}{l}\text { Profits, } \\
\text { FIM }\end{array}$ & $\begin{array}{l}\text { Runoffs, } \\
\text { kg }\end{array}$ & $\begin{array}{l}\text { Species } \\
\text { richness }\end{array}$ & SHDI & $\begin{array}{l}S W \\
\text { FIM }\end{array}$ \\
\hline $\begin{array}{l}\text { Private solu- } \\
\text { tion }\end{array}$ & $\begin{array}{l}20 \\
40\end{array}$ & 184667 & 1381 & - & 0,64 & 125749 \\
\hline $\begin{array}{l}\text { Command } \\
\text { optimum }\end{array}$ & $\begin{array}{l}23 \\
37\end{array}$ & 180079 & 1236 & 76 & 0,72 & 131879 \\
\hline $\begin{array}{l}\text { Second-best } \\
\text { instruments }\end{array}$ & $\begin{array}{l}22 \\
38\end{array}$ & 170166 & 957 & 95 & 0,98 & 126749 \\
\hline
\end{tabular}

As Table 1 shows, the private market solution in the absence of taxes and subsidies yields highest private profits, but also the highest runoffs and the lowest value for SHDI, resulting in the lowest value for social welfare. In the absence of buffer strip subsidy the optimal level of buffer strips is zero, and thus the estimate of floral species richness in buffer strip areas is zero as well in this case. The command optimum produces lower private profits because of the internalization of negative and positive externalities associated with runoffs and agro-ecosystem diversity. In the command optimum SHDI increases mainly due to the increased number of patch types via the emergence of buffer strip areas. The buffer strip areas in this solution $(0,6$ ha in total) provide 76 floral species.

How does the optimal multifunctional policy look like? As our analytical model predicts, the first-best policy consists of crop and parcel specific instruments, i.e. 60 pairs of crop and parcel specific fertilizer taxes and buffer strip subsidies (we have 60 parcels in our model, which results in 120 instruments). They are solved from the command optimum solution to reflect the size of positive and negative externalities per parcel. As an example of second best policy, we solve the optimal quadruple for the last parcel, which in our case is the $60^{\text {th }}$ hectare, to yield crop-specific instruments that are uniform with respect to parcels and thus land quality. Solving the optimal level of instruments for the last parcel with highest productivity/land quality means that the marginal revenue of buffer strips is high at lower quality parcels. The optimal level of the instruments for the last parcel are defined as follows: fertilizer tax for barley (crop 1) is $26 \%$ and for wheat (crop 2) 30\%. Buffer strip subsidy is FIM 3900 for crop 1 and FIM 4465 for crop 2. Naturally, increasing the number of instruments would bring the second-best solution closer to the first-best optimum.

We report the private solution under the second best instruments in the third row of Table 1. In this case the net-support (i.e. subsidy minus tax) is taken into account, so that the difference in social welfare between command optimum and the second best instruments reflects the welfare loss due to use of the second-best instruments. Now the private profits are lower than under command optimum. Nitrogen runoffs are clearly lower due to increase in buffer strip areas (total buffer strip area in this case is 5,9 ha). SHDI and floral species number increase also clearly compared to command optimum owing to a higher share of buffer strip areas. Moreover, more equitable area distribution between different patch types increases SHDI in this case compared to command optimum. FIM 5130 difference in social welfare compared to that of command optimum is due to implementation of second-best instruments. 


\section{References}

Aakkula, J.J. 1999. Economic value of pro-environmental farming - A critical and decision-making oriented application of the contingent valuation method. Agricultural Economics Research Institute, Publications 92. Helsinki, Finland.

Bäckman, S.T., Vermeulen, S. and Taavitsainen, V.-M. 1997. Long-term fertilizer field trials: comparison of three mathematical response models. Agricultural and Food Science in Finland 6: 151-160.

Lichtenberg, E. 1989. Land quality, irrigation development, and cropping patterns in the Northern High Plains. American Journal of Agricultural Economics 71:187-194.

Ma, M., Tarmi, S. and Helenius, J. 2001. Revisited species-area relationship in a semi-natural habitat: floral richness in agricultural buffer zones. Forthcoming in Agriculture, Ecosystems and Environment.

OECD 2001. Multifunctionality: Towards an analytical framework. 159 p. OECD, Paris.

Shumway, C.R., Pope, R.D. and Nash, E.K. 1984. Allocatable fixed inputs and jointness

in agricultural production: implications for economic modeling. American Journal of Agricultural Economics 66: $72-78$.

Vehkasalo, V. 1999. Ympäristötuen yhteiskunnallinen kannattavuus (Abstract: Social profitability of the Finnish agri-environmental programme) pp. 42-77. In: Maatalouden ympäristöohjelma 1995-1999:n taloudellinen analyysi. Agricultural Economics Research Institute, Publications 90. Helsinki, Finland. 